\title{
Erratum: "Neogene Basanites in Western Kamchatka: Mineralogy, Geochemistry, and Geodynamic Setting"' \\ [Petrology, 2007, Vol. 15, No. 5, pp. 488-508]
}

A. B. Perepelov ${ }^{a}$, M. Yu. Puzankov ${ }^{b}$, A. V. Ivanov ${ }^{c}$, T. M. Filosofova ${ }^{b}$, E. I. Demonterova ${ }^{c}$, E. V. Smirnova $a$, L. A. Chuvashova ${ }^{a}$, and T. A. Yasnygina ${ }^{c}$

${ }^{a}$ Vinogradov Institute of Geochemistry, Siberian Division, Russian Academy of Sciences, ul. Favorskogo la, Irkutsk, 664033 Russia e-mail:region@igc.irk.ru

${ }^{b}$ Institute of Volcanology and Seismology, Far East Division, Russian Academy of Sciences, bul'v. Piipa 9, Petropavlosk-Kamchatskii, 683006 Russia e-mail: puzankov@kscnet.ru

${ }^{c}$ Institute of the Earth's Crust, Siberian Division, Russian Academy of Sciences, ul. Lermontova 128, Irkutsk, 664033 Russia e-mail:aivanov@crust.irk.ru Received September 11, 2007

DOI: $10.1134 / \mathrm{S} 0869591107060069$

1. On page 498, in the caption to Fig. 5, description of (7) and (8) should read (7) compositional field of the Mount Khukhch basanitic groundmass; (8) average composition of the Mount Khukhch basa- nitic groundmass. The diagram is based on our and literature data.

2. This work was also supported by the Russian Foundation for Basic Research (project no. 07-05-00959). 